Abstracta Iranica Abstracta Iranica

Revue bibliographique pour le domaine irano-aryen

Volume 27 | 2006

Comptes rendus des publications de 2004

\title{
« Nb 25 et la formation du Pentateuque à la croisée des enjeux post-exiliques ». Transeuphratène, 27 (2004), pp. 37-67.
}

\section{Astrid Nunn}

\section{(2) OpenEdition}

1 Journals

\section{Édition électronique}

URL : http://journals.openedition.org/abstractairanica/5766

DOI : 10.4000/abstractairanica.5766

ISSN : 1961-960X

Éditeur :

CNRS (UMR 7528 Mondes iraniens et indiens), Éditions de l'IFRI

\section{Édition imprimée}

Date de publication : 15 mai 2006

ISSN : 0240-8910

Référence électronique

Astrid Nunn, « « Nb 25 et la formation du Pentateuque à la croisée des enjeux post-exiliques ».

Transeuphratène, 27 (2004), pp. 37-67. », Abstracta Iranica [En ligne], Volume 27 | 2006, document 102, mis en ligne le 02 janvier 2007, consulté le 25 septembre 2020. URL : http://journals.openedition.org/ abstractairanica/5766 ; DOI : https://doi.org/10.4000/abstractairanica.5766

Ce document a été généré automatiquement le 25 septembre 2020.

Tous droits réservés 


\section{« Nb 25 et la formation du Pentateuque à la croisée des enjeux post-exiliques ». Transeuphratène, 27 (2004), pp. 37-67.}

\section{Astrid Nunn}

Cet article est une étude détaillée du texte Nombres 25 d'un point de vue littéraire et historique. Il traite des mariages mixtes, de l'autorité de Moïse, de la reconnaissance officielle des prêtres. Tout ceci caractérise la situation conflictuelle de la communauté juive à l'époque perse et la question de savoir qui appartenait à cette communauté. Ce texte et le Pentateuque sont à comprendre comme des documents de compromis, dont la vocation consiste à surmonter les conflits et réconcilier les différentes tendances dans une communauté juive post-exilique en quête d'identité.

INDEX

Thèmes : 3.2.1. Elam

\section{AUTEURS}

\section{ASTRID NUNN}

Université de Munich 